\title{
Internet Celebrities Bodies/Emotions in China's Society 4.0
}

\author{
Adrián Scribano \\ CONICET (UNIVERSIDAD DE BUENOS AIRES) \\ adrianscribanofagmail.com \\ Zhang Jingting \\ SHANGHAI INTERNATIONAL STUDIES UNIVERSITY \\ felisazhang007@igmail.com
}

Received: 28/03/2019

Accepted: 19/09/2019

\begin{abstract}
Internet celebrities, as a group of stars spawned by the market economy and The Internet, reveal both the state of Internet culture and the transformation of mass media in China. The bodies and pictures of these 'celebs', while unique, also take on a cultural symbolism. The 4.0 Revolution is the carrier of social practices and kinds of interaction in which the social media play a very special role. In this paper we will focus on the intersections and ruptures between the bodyindividual, body-subjective and body-social (Scribano, 2007) of Chinese Internet celebrities and the articulations and links between body-image and their body-in-movement. With the introduction of Chinese social media platforms such as WeChat (微信), Sina Weibo (新浪微博), Douyin, we try to trace links between the sociability, experiences and social sensibilities of the Internet celebrities and their influence on Society 4.0.

This paper: (a) looks at the Chinese social media as a virtual platform for the Internet celebrities; (b) delves into the images and practices of the Internet celebrities; (c) highlights the link between body, sensation and perception regarding social celebrities; (d) shows the kinds of sociability and social sensibilities exhibited by celebrities in China's Society 4.0. home foreclosure) in several Catalan municipalities. It was conducted by participatory observation, focus groups and in-depth interviews with activists.
\end{abstract}

Keywords: internet celebrities, body, sensibility, China.

Corresponding author: Adrián Scribano, CIES-ESTUDIOS SOCIOLÓGICOS EDITORA. Billinghurst 1260 Piso 4, Dpto. A (CP. 1413)Ciudad Autónoma de Buenos Aires.

Suggested citation: Scribano, A. and Jingting, Z. (2019). Internet Celebrities Bodies/Emotions in China's Society 4.0. Debats. Journal on Culture, Power and Society, 4, 189-200. DOI: http://doi.org/10.28939/iam.debats-en.2019-15 


\section{INTRODUCTION}

The soaring popularity of social networks has been one of the innovations marking the dawn of the 21st century. We find them playing a role in everything from The Arab Spring to Spain's Indignados and the Occupy Wall Street movement, and in the use of mobile devices to buy anything. In this context, China, as 'The World's Factory' has turned into an industrialised, highly technological society over the last forty years thanks to the Reform and Openingup Policy, which was drawn up by Deng Xiaoping in 1978. It was he who made Capitalist reforms to a Communist Command Economy and, in so doing, lifted over 740 million Chinese out of poverty. ${ }^{\mathbf{1}}$

Entering the 21st Century, China also faces the 4.0 Revolution. Smart Cities, Smart Industries, cyberphysical systems (the Internet of Things (IoT), Cloud Computing); Cyberbotics, Total Automation, Revolution 4.0 are all terms that we have become familiar with. In this sense, China's Online Celebrity phenomenon has spawned an industry.

In "Bodies of Digital Celebrity", Pearl and Polan (2015: 190) insist that in The Digital Age, the new media industries can puff up ordinary people as talented individuals. Yet we cannot ignore the importance of bodies.

"It's easy in a digital age that speaks of the virtual to think that celebrity is now something ineffable (......). But even as new media can create celebrity at a distance, across the gulf of time and space, it still often comes back to bodies."

The authors (Pearl and Polan, 2015: 190) also mention the link between traditions in culture studies and the issues of bodies, of corporeality, of materiality.

"Much of the power of celebrities lies in their vivacity."

Wang Junbing (2018) analyses the concept of 'Grassroots Media', which could give everyone the chance

1 Statistics from Xin Hua News Agency. Available at http://www. xinhuanet.com/politics/2018-12/10/c_1123833866.htm to become a celebrity. However, these celebrities need wide-ranging know-how to supply what the public demands. That is why one needs to assiduously study the latest trends, news, and social language found on various platforms (Facebook, YouTube, LINE, Instagram etc.).

In addition, Lin (2018) investigates the performance of the body with the self-governance practices imposed by China's Party-State, especially in the case of female celebrities. The author used the terms "staging the body", "defending the body" and "instrumentalising the body" to describe how Ye Haiyan, as a female 'celeb' performs with her body to reach her goals.

"Ye has staged her body as a channel of political transgression, defended her body for sexual rights and instrumentalised her body for activist goals. In this sense, the practices of this female Internet celebrity's body performances are never external to the Party-State's rationality but internal to its governmental project, which raises issues of resistance with regards to the microphysics of the body." (Lin, 2018: 777)

$\mathrm{XuXu}$ and Stephen Pratt look at the Chinese Generation Y and use Self-Congruity Theory to understand the congruence between endorsers and potential tourists to evaluate the effectiveness of endorsement. They believe that in the tourist area, destination marketers should consider using Social Media Influencers (SMIs) to promote tourism-related products and destinations. Zhang Yanhui and Chen Fuwen (2018) examine the influence of online celebrities in the advertising business and the way this has changed customers' awareness and boosted certain kinds of consumption.

In 2015, the Chinese Premier, Li Keqiang, proposed a strategic plan for the country dubbed "Made in China 2025” (中国制造 2025). Its goals include: (1) boosting domestic Chinese content of core materials to 40 per cent by 2020 and 70 per cent by 2025; (2) focusing on high-tech fields, including the: pharmaceutical, automotive, aerospace, semi-conductor, IT, and robotics industries (Li, L. 2018). As a result, this plan 
is also considered the Chinese version of Industry 4.0, similar to the concept of German Industry 4.0. "Made in China 2025" aims to foster innovation and remove bottlenecks in industrial development to transform China from a world factory into a fullyfledged industrial power.

According to the 2018 China Online Celebrity Economic Development Insight Report,

“By May 2018, cyber celebrities with over 100,000 fans rose by 51 per cent from a year ago. Their total followers rose 25 per cent to 588 million". 2

The boom in Internet celebrities has greatly influenced Chinese society. It already commands huge audiences and it is likely that these will continue to grow.

Internet celebrities have a huge influence and social impact on China, especially at the moral level. They set society's standards and moral direction and thus shape political sensibilities. Given that we know that body(ies) and society(ies) are systematic objects of research in which affectivity and sensibilities are strongly present, the numerous theories on emotions can be grouped under a tripartite classification: Determinism, Social Constructionism, and Social Interaction.

Gross and Feldman Barrett (2011) tried to evaluate the differences of perspective on the "generation" and/or "regulation" of emotions by splitting current scholarly perspectives on the subject into four large groups: (1) models of basic emotions; (2) evaluative models; (3) psychological construction models; (4) social construction models.

For over a decade, Scribano has sought an explanation for the importance of the "existential turn" in social theory ${ }^{3}$, advocating a closer link between the studies

22018 China's Internet Industry Report. (online) http://www. iresearchchina.com/content/details8_40769.html, access 21st March.

3 Scribano, A. Complex societies and social theory. Social Science Information. 1998, 37, 3: 493-532. of the body and emotions ${ }^{4}$. He has also argued the need to explore the intersection of these works by looking at the roles both colours and feelings play in relation to the issues raised ${ }^{5}$.

However, when we talk about celebrities in China, we should bear in mind that little research has been done on the relationships between 'celebs' bodies, emotions, and social influence. The Internet and New Social Formation in China ${ }^{6}$ (2016) shows how entertainment-consuming users form specific audiences through the mediation of technologies in today's networked society. It also delves into how fans are turned into target audiences. Cyber-nationalism in China: Challenging Western media portrayals of internet censorship in China ${ }^{7}$ (2012: 3) describes the emotions of web users in China (their frustrations, attitudes and so on) and compares Liberalism in Chinese and Western communities.

"The rising tension between Chinese bloggers and Western media has highlighted a major difference in the understanding of the natures of nationalism and censorship between China and the West."

There is a close link between changes of sensibilities and Society 4.0's transformations.

Advances in high-tech have led us to Society 4.0, in which mobile communication devices (cell phones,

4 Scribano A. Geometría del conflicto: estudios sobre acción colectiva y conflicto social. Córdoba: Universitas; 2005. Scribano A. Primero hay que saber sufrir! Hacia una Sociología de la 'espera' como mecanismo de soportabilidad social. In: Scribano A, Lisdero P (Editors). Sensibilidades en juego: miradas múltiples desde los estudios sociales de los cuerpos y las emociones. Córdoba: CEA-UNC-CONICET; 2010.p.169-192. Scribano A. Sociología de los cuerpos/emociones. RELACES. 2012, 10: 93-113.

5 Scribano A. Policromia corporal. Cuerpos, Grafías y Sociedad. Córdoba: Sarmiento Editor; 2007.

6 Zhang, W. The Internet and new social formation in China: Fandom publics in the making. Abingdon-on-Thames: Routledge, 2016.

7 Jiang, Y. Cyber-nationalism in China: Challenging Western media portrayals of internet censorship in China. Adelaide: University of Adelaide Press, 2012. 
tablets) have become spaces for production, editing and for storing images. Scribano (2017) argues that Mankind is going through a stage in which our senses converge with the world of technology in a quest for discovery and authenticity.

Chinese social media such as WeChat, QQ, Weibo is a paradigmatic example of the metonymic way practices are changing our ways of forging social bonds, experience, and sensibilities. The McKinsey consulting firm states:

"Industry 4.0 as a new phase in the digitalisation of the manufacturing sector is driven by four engines: an increase in the volumes of data handled by industrial companies; increasingly powerful and cheap computers; the ability to analyze and process data; the continuous improvement in the interaction of people with machines, robots and 3D printers." ${ }^{8}$

Social Networks spring up and are globalised in the context of the convergence of these trends: the widespread use of social networks, the 4.0 Revolution and the emergence of 'image makers'. It is against this background that one can see the emergence of 4.0 societies. We can see practices typifying social networks in general (digital marketing, charity and political campaigns, etc.). Other practices have either already been consecrated or are being consolidated.

This paper: (a) observes the Chinese social media, which act as a virtual platform for the country's internet celebrities; (b) delves into the images and practices of the internet celebrities; (c) highlights the link between body, sensation and perception in relation to the whole social celebrity scene; (d) reveals the kind of socialisation and social sensibilities arising in Society 4.0 through these celebrities.

8 "Are you ready for the 4th industrial revolution?" McKinsey \& Company. (online). https://www.mckinsey.com/businessfunctions/operations/how-we-help-clients/capability-centernetwork/overview, access 20th March 2019.

\section{BODY / EMOTION A FIRST APPROXIMATION}

The presence of celebrities in social networks takes place in and through bodies / emotions. It is the sensibilities associated with the presence of these bodies that allow us to better understand societies.

One path to understanding the body's role lies in looking at the distances and bridges between bodyindividual, body-social and body-subjective. This entails underlining the connections between the experience of the body as organism, the experience of the body as a reflective act, and the practice of the body as a social construction. A body-individual refers to phylogenetic logic, to the articulation between the organic and the environment; a body-subjective takes wing from self-reflection, in the sense of the ' $\mathrm{I}$ ' as a centre of gravity through which multiple subjectivities are formed; and finally, a body-social is society made flesh, as it were (sensu Bourdieu).

These three basic body practices both organise and are organised by logics regulating the senses. Gradual progress and constant metamorphosis of sensibilities are ways of appropriating the body's energy, the connections between diverse body-sensations which, taken together, form one of the pillars of domination and of autonomy.

This kind of ontological re-description demands a discussion of the differences between body and social energies but lack of space precludes us from embarking on one here. To maintain the 'state of things' assigned to the individual body, it is vital that body-energy becomes an object of both production and consumption. Here, it is body energy that is the source of the social energy found in society. The power to plan, carry out, and resolve the consequences of the actions of agents is what constitutes social energy.

A second path to understanding the body's role is to draw on and reconstruct what we already know about the body through body-image, body-skin and body-movement. These three ways of inscribing the corporal in a narrative offer a reconstructive analysis 
of how we can see the corporal aspects of celebrities' impacts on sociability, sensibility, and experiences of everyday life as social phenomena.

First, body-image is an indicator of the process of 'I see they see me'; body-skin indicates the process of how one 'naturally-feels' the world; and body-movement is the inscription of the body within a field of possible actions. These three ways of reconstructing body experiences may be seen as paths for analyses and interpretations of how bodies appear on the social stage. Tensions and processes are at work between: the social parts of the body; the body there; posture; the body as a significant social structure; the elaboration of the body-image, which every agent must build and manage.

The senses appear to be natural but they are also the results of a social process, which give rise to the social construction of the body-skin. Consequently, sociability and social sensibilities get entrenched as the 'natural' way of 'feeling the world'.

Body-movement is a mediation of both the power and impotence of the body and social energies. There are ways in which bodies can act, that is to say that they are able to act depending on social energies and social inertia. In other words, there are certain kinds of action that embody the social geometries of displacement as well as social inertia. In this process, seeing, smelling, touching, hearing and tasting coalesce into potential sociability, indicating social devices for the regulation of sensations.

In other words, such actions bring bodies closer or distance them from the aforementioned dialectics. Sensations, as a result and antecedent of perceptions, give way to emotions which can be seen as the manifestation of the action and effect of feelings. They are rooted in how we feel about the world, building perceptions associated with socially-constructed forms of sensations. At the same time, organic, social senses also permit mobilisation of uniquely individual traits while they carry out the 'unnoticed work' of incorporating the social via emotions.
A privileged form of connection between collective action and social fantasies and phantoms lies in the fact that the body is the locus of conflict and order. It is the place and Topos (Gk. Tóros) of conflict through which much of the logic of contemporary antagonisms passes. From this standpoint, we can see the formation of a political economy of morality, that is to say, forms of sensibilities, practices and representations that put domination into words. In this context, we understand that mechanisms determining what is socially tolerable are structured around a set of practices-made-body who purpose is the systematic avoidance of social conflict. The processes displacing the consequences of antagonism are presented as specular scenarios unpinned (dis-embedded) in space and time. These allow both individual and society to accept the notion that social life always takes a certain form.

Then there are devices for regulating sensations. These consist of processes for the selection, classification, and the elaboration of socially-determined and distributed perceptions. Regulation implies tension between the senses, perceptions and feelings that organise special ways for individuals and groups of "seeing oneself-in-the-world" and of "appreciationin-the-world".

Chains and cognitive-affective schemas that connect (and disconnect) social practices as narratives and worldviews made flesh, are processes that we characterise as ideological. The identified mechanisms and devices are a practical and procedural hinge on which the interactions between emotions, bodies and stories hang. Systems' social bearability mechanisms do not operate either directly or explicitly as "attempted control", nor "deeply" as processes of focal points of persuasion. These mechanisms operate "almost unnoticed" in the paths beaten by habit, in the frames of common sense, through the construction of sensations that seem the most "intimate" and "unique" possessed by each individual as a social agent. The social media offer opportunities for ordinary people to become celebrities and exercise influence as social agents. Their behaviours and social practices affect fans' emotions and actions. 
The politics of emotions require regulation, shaping how social order is produced and made bearable. In this context, we understand that social bearability mechanisms are structured around a set of practices that have become ingrained and whose main purpose is the systematic avoidance of social conflict.

The forms of sociability and experience are strained and twisted as if constrained within a Moebius Strip along which sensibilities arise from regulatory devices and the aforementioned mechanisms. The need to distinguish and link the possible relations between sociability, experience, and social sensibilities becomes crucial at this point. Sociability is a way of expressing the means by which agents live and interactively co-exist. Experience is a way of expressing the meaning gained while being in physical proximity with others, as a result of experiencing the dialogue between the individual body, the social body, and the subjective body, on the one hand; and the natural appropriation of bodily and social energies on the other. For the body to be able to reproduce experience and sociability, bodily energy both needs to be produced and consumed. Such energy can be understood as the force needed to preserve the 'natural' state of affairs in systemic functioning. At the same time, the social energy shown through the social body is based on the way individuals' energy is spent and apportioned through movement and action.

Thus, sensations are distributed in accordance with the specific forms of bodily capital; and the body's impact on sociability and experience reveals a distinction between the body of appearance, body of flesh, and body of movement. Social sensibilities are continually updating the emotional schemes that arise from the accepted and acceptable norms of sensations. They fall just a little long or short of the interrelationships between sociability and experience. Sensibilities are shaped and reshaped by contingent and structural overlaps taking diverse forms of connection/disconnection among various ways of producing and reproducing the politics of the body and the emotions.

The politics of sensibilities are understood as the set of cognitive-affective social practices tending to the production, management and reproduction of horizons of action, disposition and cognition. These horizons refer to: (1) the organisation of daily life (the day-to-day routine, wakefulness/sleep, eating/ fasting, etc.; (2) information to sort preferences and values (adequate / inadequate; acceptable / unacceptable; bearable / unbearable); (3) parameters for time / space management (displacement / location, walls / bridges; enjoyment).

Three concepts become relevant in this context: "practices of wanting", "practices of feeling" and "interstitial practices". Practices of feeling are those that involve heterogeneous sets of relationships between sensations and emotions. Interstitial practices are those social bonds that break the political economy of the moral and that structure sensibilities. 'Wanting practices' involve the potential links between hope, love and enjoyment, and are social relations that link us to "doing with" the other. Associations between the aforementioned practices, social bearability mechanisms, and devices to regulate sensations might help us better understand the state of social sensibilities.

In the next section we reconstruct the scenarios and contexts where the practices of these bodies are carried out within the Internet framework.

\section{CHINESE SOCIAL MEDIA}

It is well known that China - the world's largest social-media market - differs greatly from the western world for there is no Facebook, no Twitter, no YouTube. So, what do people use in China? The "Top 10 Social Media Sites to Connect with Chinese Consumers" 9 lists: WeChat, Sina Weibo, Youku, Miaopai and Yizhibo, Douban, DianPing, Renren, Tencent Weibo, PengYou, Diandian.

9 Top 10 Social Media Sites to Connect with Chinese Consumers Available at https://smallbiztrends.com/2017/07/chinesesocial-media-marketing.html 
WeChat, also known as Weixin, is a multi-purpose mobile voice and text app. It was invented in 2011 and now has over one thousand million monthly active users (Lie and Cao, 2014). Sina Weibo, which means 'microblog', is like Twitter and Facebook rolled into one. Sina Weibo's content is fast-moving and the celebrities always have their followers and space to discuss some 'hot'/listening topics in Weibo. Youku is similar to YouTube, containing videos covering various topics. Miaopai and Yizhibo are platforms with live streaming and short videos. Douban is a space where people can share their opinions on books, films, music etc. Dianping has similar features to Yelp and TripAdvisor, letting users review restaurants. Renren operates much like Facebook but is no longer as active as Weibo or WeChat. Tencent Weibo is another "microblog", where users can share videos, photos, and text messages of up to 140-characters. PengYou, or "friend" in Chinese characters, is a platform with social features and is another product from the company that came up with Tencent Weibo.

An internet celebrity is someone whose fame mainly stems from their Internet presence. It refers to a person who is popular online because of an event or behaviour pattern and who influences society (which tends to copy its idol). Internet celebrities perform actively in the social media and they undergo a metamorphosis from social media phenomenon to a-social, political and economic influencer.

The stars' emotions, aesthetics, and values are changing consumption patterns, lifestyles, and public ideas, exerting a deep influence on Chinese society. Zhang and Seta (2018) analyse the situation and functions of online celebrities or Wanghong (the Mandarin Chinese term for these modern idols) in the culture of grassroots popularity. Becoming an online celebrity in China has become a profitable 'profession', an inspirational role model, a morally questionable by-product of internet economies, and in general a widely-debated social phenomenon among local users. The authors believe that the popularity of the Wanghong arises from Chinese social media sites and from narratives of profes- sionalism and economic aspirations that strike a chord in contemporary China.

According to the Report on Internet Attitudes in China $2018^{\mathbf{1 0}}$, the most discussed topics covered "new era", "good life" and "the universal two-child policy". "New era" is a Chinese umbrella term for the innovative, international, better living conditions, better education and fairer gender relations. "Children, youth, work, and food have become "the four great things in a good life." In 2016, China brought in the "universal two-child policy", "health" and "husband" became the main factors influencing the desire to have children. Another point made in the 2018 Report is that there are two major semantic communities in the digital field in China. One mainly involves "a new era of social diversification"; the other community covers 'new era' celebrities, who are young, hot-blooded, patriotic and keen on social responsibility. Thus online celebrities in China's digital society have greater scope for influencing others through the 'tools' of the country's social media and thus contributing to China's new age.

\section{EMOTIONS, IMAGES AND PRACTICES}

China has seen massive changes over the past 40 years. If we look at the experience of three generations (X, $\mathrm{Y}$ and $\mathrm{Z}$ ), one can see how the country's transformation has changed people's lives and shaped how they see the world. Generation X (early-to-mid 1960s to the early 1980s) was born during China's Cultural Revolution (1966-1976). Their educational experience and life style were deeply influenced by politics. Members of this generation in China grew up believing that loyalty to the State and institutions would be rewarded. Then with the Reform and Opening-up Policy in the 1980s, many western elements made a

10 《中国网络社会心态报告（2018）》发布三大话题引发 关注, 中国新闻网，2019年01月21日. Three topics of Report of the attitudes of internet in China 2018. Web of Chinese News. 21st January 2019. (online) https://www.pishu.com. cn/skwx_ps/bookdetail?SitelD $=14 \& \mid D=10197082$ access 21 st March 2019 
big impact on China with the advent of pop culture, American cinema, nightlife, American brands, and Western teen slang. China also developed a strong cell phone culture, and soon had the highest number of mobile users in the world. Thus Generation Y (the 1980s and 1995s) grew up with societal change. These individuals were born under China's one-child policy, which was introduced in 1979. As a result, most of them were only children. With the love and care of two parents and four grandparents, they tend to be self-confident and have high self-esteem.

Then Generation Z (mid-1990s to mid-2000s) also became a social phenomenon. With China's booming economy and rapid technological development, these individuals have different lifestyles and shopping habits. Generation $\mathrm{Z}$ is the first Chinese generation to have been born in a fully modern, digitalised country so they are highly connected and willing to share their feelings through social media. Many of them are making live broadcasts on Douyin, Taobao, Weixin etc. They have their own fans and become online celebrities. It is within this framework that we need to examine the feelings elicited by today's Chinese celebrities and the influence these 'stars' exert.

In examining reflections and theories on affection, emotions and feelings ${ }^{\mathbf{1 1}}$, we found references to seventeenth, eighteenth and nineteenth-century social philosophers, including Descartes, Montesquieu, Bentham, Pascal, La Mettrie, and Darwin, among others.

Early social scientists such as Comte, Durkheim, Fourier, Marx, Sombart, Simmel, and Weber also stated that emotional control is yet another form of discipline, and that it affects social practices, relationships and worldviews in a reciprocal, dynamic way ${ }^{\mathbf{1 2}}$. To a great extent, such concerns are also addressed in contemporary social theory from different perspec-

11 Smith H, Schneider A. (2009). Critiquing models of emotions. Sociological Methods \& Research, 37,4, 560-589

12 Gross J, Feldman Barrett L. (2011). Emotion generation and emotion regulation: one or two depends on your point of view. Emotion Review, 3, 8-16. tives by Bourdieu, Giddens, Foucault, Agamben and Esposito. In this context, Brian Turner and David Le Breton are seen as forerunners of social studies on the body, as are Kemper's, Hochschild's, Scheff's, Collins', and Illouz's studies on the emotions.

A different perspective on the theoretical traditions usually underpinning studies in this field is given by classic authors on the subject: Nietzsche, MerleauPonty, Spinoza, and Marx. Yet other approaches are suggested by the work of contemporary sociologists such as Goffman, Simmel and Elias, by the philosophy of Derrida, Butler and Deleuze, and by the psychoanalysis of Freud, Lacan and Zizek.

The popularity of online celebrities in China shows the direction taken by ordinariness. Footage of the celebrities is not confined to television and films, and the 'celebs' are clearly identifiable with common folk, unlike the Hollywood stars of yore. With the swift development of social media, the public chooses its idols to suit its tastes. The new online celebrities know how to grab the public's attention by sharing their own experiences and emotions. ${ }^{13}$

In the case of online celebrities in China, one can also see the interaction of their bodies and society. Their bodies and images on the media can be circulated, downloaded and copied as symbols and models. The online stars are part and parcel of consumers' daily life. On the other hand, as common people, we are all under the thrall of online celebrity culture. As a result, more and more people become fans (whether voluntarily or passively) and relate intimately to the celebrities. Here it is opportune to look at body positions and modalities in a broader context.

The tension between individual, subjective, and social bodies is one of the keys that will shed light on the

\footnotetext{
13 For "emotion management" view see Hochschild, A. R. (1990). Ideology and emotion management: A perspective and path for future research. En T. D. Kemper (ed.), Research agenda in the sociology of emotions (p 117-142). Nova York: University of New York Press.
} 
connections between the geometries of bodies and grammars of action that are part of China, Asia and the Global South. The phenomenon of online celebrities also creates tensions and sense when joining the corporal perspective with view from the standpoint of sensations. The logic of 'attracting fans' in the form of a host of "likes" may be easy and convenient but it can also give rise to problems and social tensions. As Wang Bing (2018: 147) says, "With a collective carnival, a small text or a video could get numerous clicks, spread, comments and even a virus-like witness. The number of followers has become the vote of the celebrities. In this sense, the new media has become a digitalised 'celebrity-making' machine."

As mentioned above, this paper seeks to clarify the practices of Internet celebrities in China to shed light on the current politics of sensibilities.

\section{CELEBRITIES: BODY, SENSATIONS AND PERCEPTIONS} The 2018 China Online Celebrity Economic Development Insight Report ${ }^{\mathbf{1 4}}$ published by Sina Weibo and I-Research, concludes that the scale of online celebrities' industry is constantly expanding and many new areas are emerging. The number of celebrities is rising and the age of fans is falling. Advertising has become the easiest way for celebrities to make money and expand their influence - something that has been recognised by advertisers. From the gender perspective, the number of male celebrities rose by $49.9 \%$ in 2008 . Over half of the celebrities are from big cities such as Beijing, Shanghai and Guangzhou. One should also note that celebrities are generally well-educated. According to the survey, $77.6 \%$ held a bachelor's degree and 13\% had a master's degree. The ranking of online celebrities in China $2018^{15}$ analysed by Daily Web, shows that the first five celebrities are 回忆专用小马甲 (small vest

142018 China Online Celebrity Economic Development Insight Report (online)

15 Ranking of online celebrities in China 2018 (online) http:// www.enet.com.cn/article/2018/0818/A20180818052679. html access 21st March 2019. for the memory), papi 酱 (papi sauce), 小野妹子学 吐槽 (gossip from sister Xiao Ye), 我的前任是极品 (a crazy ex) and 同道大叔 (Tong dao A uncle). From the

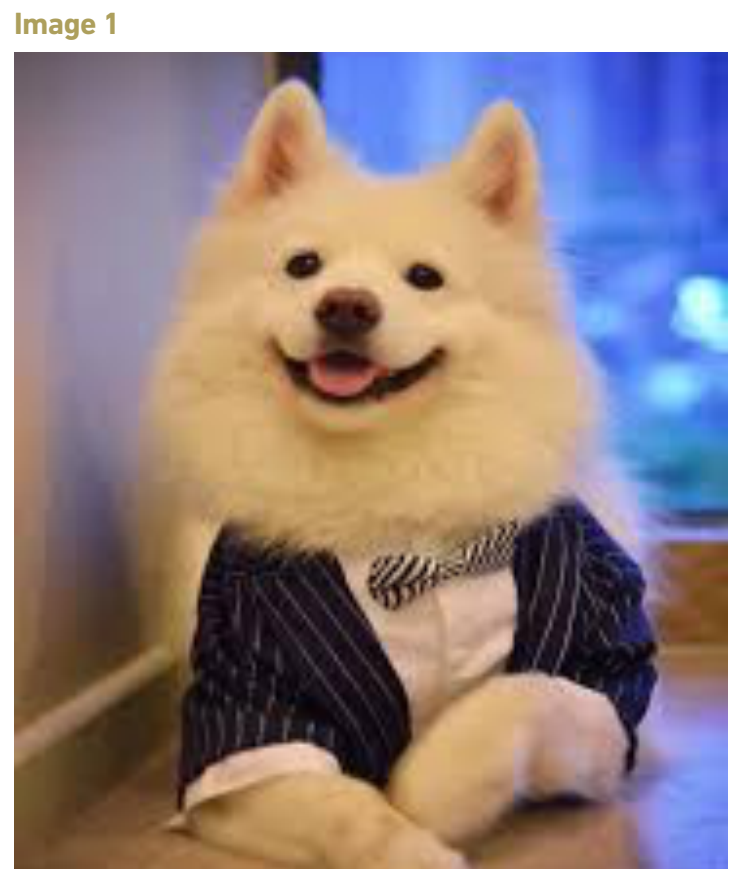

回忆专用小马甲 «15 (small vest for the memory») Source: http://m.gaochengnews.net/wanghong/24647.html

Image 2

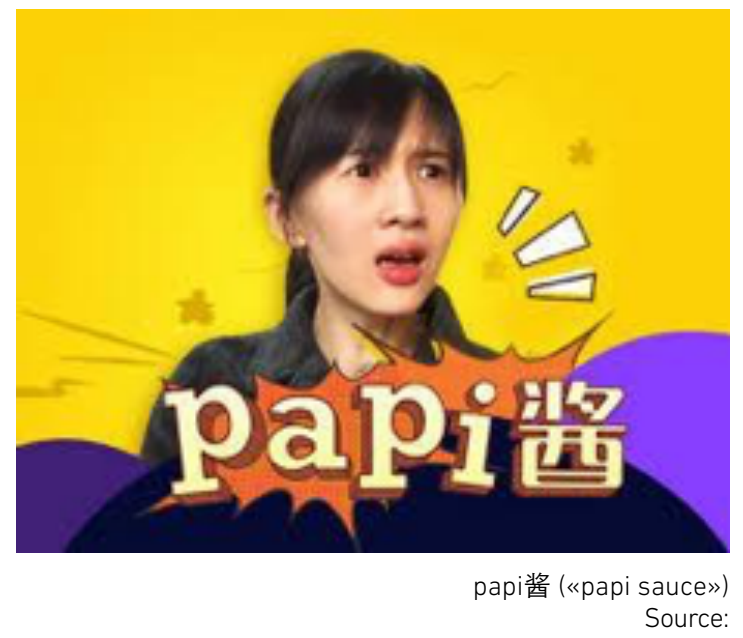

http://www.ikanchai.com/article/20160713/88465.shtm 
weird nicknames, we might guess that these are not actors or actresses but rather ordinary people with lots of online fans. Given that they lack the professional training of film stars, when they achieve fame, they often run into trouble when their traits and acts are at odds with their social identities.

Online celebrities could come up with emotional branding to forge strong ties with consumers. They could go online to accompany their fans and use their unique styles to capture yet more fans - for instance, through text, images, photos, videos and live broadcasts to show their sensations, understanding and experiences of some products, news items, etc. Many celebrities undergo cosmetic surgery, put on make-up, or wear bizarre clothes to please their fans when they broadcast live.

The short video app Douyin (launched as 'A. me' in September 2016) not only offers a space for celebrities but also for ordinary people to express themselves. Originally conceived as an app for user-made music videos, Douyin is now multi-functional and covers everything from pranks to pets and sport stunts. Every clip is up to 15 seconds long and the app offers myriad editing tools, filters, and effects, such as slow-motion and camera blurs.

The impressions woven by online celebrities create sensations that give rise to two worlds - an internal one and an external one. The former is of a social, subjective, nature. The latter covers what we might call 'the natural world'. Such configurations are formed in a dialectic tension between impressions, perceptions and their results, giving sensations the 'meaning' of a surplus or excess, bringing them closer and placing them beyond the dialectic.

In contemporary Chinese society, one can see the reflection of body-individual, body-subjective and bodysocial from the popularity of online celebrities. Their body-subjective is the self-expression of their body- individual, but affects fans' multiple body-subjective. Their body is also a social body that exerts great influence on Chinese society. For example, Papi 酱 attended China's Central Academy of Drama, where she received her bachelor and master degrees. She has worked in entertainment as an actor and assistant director. Now, nicknamed "Papi 酱", she is an internet celebrity who shot to fame by posting original sarcastic videos via social media. She uses self-expression to discuss burning social issues and has her "own opinions". Therefore, Image 3

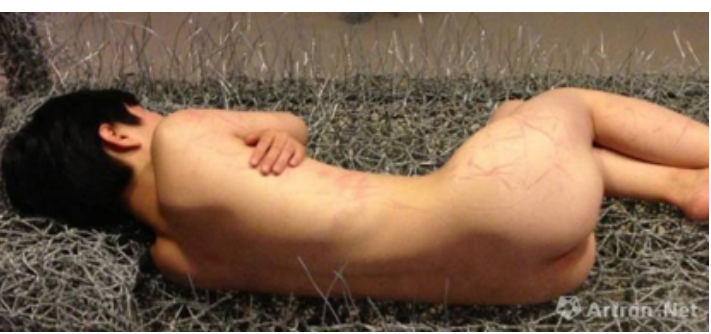

Exhibition de Zhou Jie "36 Days" Source: https://news.artron.net/20170725/n946895.htm

her body-image is not individual and fractal but has "social functions", expressing the "daily", common body. Many ordinary people are inspired by her example, using their bodies in artistic ways and go on to become online celebrities.

In 2014, Zhou Jie, an artist, put on a personal show called "36 Days" that revealed her sleeping naked in an exhibition space. This became a social event and many people criticised her, arguing the toss as to whether the show was Action Art or Erotic Art. Her body is not a self-expression of her feelings but rather a social body that society beholds.

The Internet celebrities try to take advantage of their body-image to influence their fans' 'natural feelings' and in so doing, build the body-skin of the people and spawn a body-movement akin to sociability.

16 He always uses the profile of his dog 'NiuNiu' to make his audience laugh 


\section{FINAL REFLECTIONS}

Sullivan and Kehoe (2017) stress the importance of celebrity morality given that "In China, the State, which has long promoted role models for their patriotism, heroism or exemplary role-fulfilment, uses celebrities as a vehicle for promoting nationalism, traditional virtues and the pursuit of modernity. It has identified celebrities as purveyors of "spiritual goods", exhorting them to "perform conscientiously, behave respectfully" and "take the lead in setting an example for society." Chinese celebrities need to create positive images and be a spiritual model for the public. That is why it is important to understand the policy of emotions as a strategy for constructing social sensibility.

In China, sensibilities are supposed to reflect 'Core Socialist Values' covering: prosperity; democracy; civility; harmony; freedom; equality; justice; The Rule of Law; patriotism; dedication; integrity; friendship. The production and consumption of Internet celebrities in China is thus conditioned by this context. In this sense, the celebrities are considered as the vehicle and the expression of "voices from the top" to educate and rule people. On the other hand, the machine gives ordinary, common people the chance to become stars in online talent shows. Thus the celebrities also represent the "voice from the lower and middle classes" on social issues, including justice and equality.

Chinese social media has its own tools such as WeChat, QQ, Weibo etc. in which Internet celebrities perform. Micro-celebrities for micro-environments and the masses light two paths for turning one's personal image into "popularity", "fame", and "recognition". The culture of "grabbing attention" has become a planetary phenomenon and is part of a life lived through images enshrining the notion of instant enjoyment and gratification. The images and practices of China's online celebrities embody collective attitudes and are expected to obey China's Internet management policies and to contribute to society as a whole. In such a context, ordinary people have a greater chance to become celebrities and make their voices heard.

Finally, Society 4.0 is shaping the digital economy. The sensations and emotions of China's online celebrities enshrine sociability and arouse social sensibilities. Internet celebrities open a window on the daily life of the Chinese today, revealing their concerns, worries, hopes, and dreams in a country that is advancing rapidly on a high-tech path, mirroring the giant strides the country has made over the last forty years.

\section{BIBLIOGRAPHIC REFERENCES}

Gross J, Feldman Barrett L. (2011). Emotion generation and emotion regulation: one or two depends on your point of view. Emotion Review, 3, 8-16.

Hochschild AR. (1990). Ideology and emotion management: a perspective and path for future research. In Kemper T.D editor. Research Agenda in the Sociology of Emotions (pp.117-142). New York: University of New York Press.

Jiang, Y. (2012). Cyber-nationalism in China: Challenging Western media portrayals of internet censorship in China. Adelaide: University of Adelaide Press.

Li, L. (2018). China's manufacturing locus in 2025: With a comparison of "Made-in-China 2025" and "Industry 4.0". Technological Forecasting and Social Change, 135, 66-74.

Lien, C. H., \& Cao, Y. (2014). Examining WeChat users' motivations, trust, attitudes, and positive word-of-mouth: Evidence from China. Computers in Human Behavior, 41, 104-111.

Lin, Z. (2018). Performance of the body: Chinese female celebrity's practices of self-governance. Gender, Place \& Culture, 25(5), 775-778. DOI: 10.1080/0966369X.2018.1461080

Pearl, S., \& Polan, D. (2015). Bodies of digital celebrity. Public culture, 27, 1 (75), 185-192.

Smith H, Schneider A. (2009). Critiquing models of emotions. Sociological Methods \& Research, 37 (4), $560-89$. 
Scribano, A. and Lisdero, P. (Eds) (2019) Digital Labour, Society and Politics of Sensibilities Palgrave Macmillan. UK

Scribano, A., Timmermann Lopez, F., Korstanje, M. E. (Eds.) (2018) Neoliberalism in Multi-Disciplinary Perspective. Palgrave Macmillan. p.226

Scribano, A. (2018) Politics and Emotions. Houston USA: Studium Press LLC. p.240

Scribano, A. (2017) Normalization, enjoyment and bodies/emotions: Argentine sensibilities. New York: Nova Science Publishers. p.236

Scribano A. (2007). Mapeando interiores. Cuerpo, conflicto y sensaciones. Córdoba: Sarmiento Editor.

Scribano, A. (1998). Complex societies and social theory. Social Science Information, 37, 3, 493-532.

Sullivan, J., \& Kehoe, S. (2019). Truth, good and beauty: the politics of celebrity in China. The China Quarterly, 237, 241-256.

Wang Bin.(2018). The culture of celebrities, the consumption and the affective labour of the fans - three cases of the Wanghong phenomenon in China. New Comments Tianfu, (3), 144-151. 王斌. (2018). 网络时代的名人 文化,“粉丝”消费与情感劳动——我国网红现象研究的三重议题. 天府新论, (3), 144-151.

Wang Junbin. (2018). In the era of celebrities online: between the expression of oneself and wise study, Monthly Education Research, 12，31-43. DOI: 10.3966/168063602018120296003.王俊斌. (2018). 网红世代的自主学习: 在展现自我与智慧学习之间. 教育研究月刊，12，31-43. DOI: 10.3966/168063602018120296003

Xu, X., \& Pratt, S. (2018). Social media influencers as endorsers to promote travel destinations: an application of self-congruence theory to the Chinese Generation Y. Journal of Travel \& Tourism Marketing, 35(7), 958-972. DOI: $10.1080 / 10548408.2018 .1468851$

Zhang, G., \& de Seta, G. (2018). Being "red" on the internet: The craft of popularity on Chinese social media platforms. In Microcelebrity Around the Globe (pp. 57-67). Bingley: Emerald Publishing Limited.

Zhang Yanhui \& Chen Fuwen. (2018). Influences of the different types of advertisement on customers' awareness and consumption. The case of the Internet celebrities and their advertisement. Quarterly Administration and Commerce, 19(3), 257-282. 张彦辉\&陈福文. (2018). 社交广告类型在社交广告知觉对消费行为意图影响之差 异探讨一以网络红人广告资讯为例。商管科技季刊, 19(3), 257-282.

\section{BIOGRAPHICAL NOTE}

\section{Adrián Scribano}

Adrián Scribano is the Lead Researcher of CONICET, Gino Germani Research Institute (IIGG) at the Faculty of Social Sciences, Universidad de Buenos Aires and Director of CIES (Centre for Sociological Research and Studies).

\section{Zhang Jingting}

Zhang Jingting was awarded a PhD in Social Sciences from Universidad de Buenos Aires. She is a Lecturer and is currently undertaking post-doctoral studies at SISU. Zhang is a member of GESEC (Group for Sociology of the Body and Emotions) at the Gino Germani Research Institute (IIGG) at Universidad de Buenos Aires and is a member of CIES (Centre for Sociological Research and Studies).

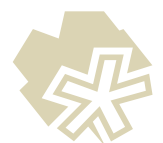

